\title{
Stress as a Threat and a Challenge for Social Workers and their Profession ${ }^{1}$ Michal Kaczor
}

\begin{abstract}
The main objective of this paper is to present stress as one of the long-standing threats of the 21 st century, especially in the context of the social work profession and its performance. The following objective is to introduce the coping strategies or the ways in which individuals - social workers - can cope with stress. Stress is seen as a potential challenge throughout the article. In this context, emphasis is placed on mindfulness as one of many possible tools to overcome the threat of stress by turning it into a challenge, that is, effectively working with stress. Neither the possibilities of cultivating mindfulness in the everyday life of social workers nor the pitfalls associated with its practice (which need to be pointed out) are omitted.
\end{abstract}

Key words: stress, personality, mental hygiene, mindfulness, coping

\section{Introduction}

This article responds to the current serious issue of the 21 st century - stress. This has become a phenomenon representing a threat to the mental and physical health of individuals (social workers) over time, being almost constantly a part of the discussions through media, various literary sources or authorities. As a main example of this, the Ministry of Labour and Social Affairs of the Czech Republic can be named. The main objective of the study is to present stress as one of the long-standing threats of the 21 st century, especially in the context of the social work profession and its driving force - social workers; in addition, to introduce coping strategies, that is, ways in which individuals - social workers - can cope with stress. Stress is seen as a potential challenge throughout the article. In this context, emphasis is placed on mindfulness as one of many possible tools for overcoming the threat of stress by turning it into the challenge. It is a tool for effectively working with stress, respectively with the burden carried by the social worker (not only) during his or her profession. Neither the possibilities of cultivating mindfulness in the everyday life of social workers nor the pitfalls associated with its practice (which need to be pointed out and further analysed) are omitted. 


\section{Stress in Social Work of the 21 st Century}

Stress, a subject of this article, is (in essence) intact with the pace of the 21 st century society and is closely related to its specifics. Not without reason is it associated with the major threats of contemporary postmodern society. Social work is then unavoidably realised in such a setting and context. The fact that stress is a serious problem which should not be underestimated can be derived from the many warnings that surround us. For example, the World Health Organisation (WHO) warns that stress is becoming the biggest health risk of the 21st century. ${ }^{2}$ There is another fact added into an enflamed debate: the Ministry of Labour and Social Affairs of the Czech Republic has publicly admitted that 'Stress is one of the most serious problems that we face today in the area of safety and health at work in Europe. Almost every fourth employee is exposed to stress. It is clear from studies that it is also the cause of 50 to $60 \%$ of all missed working days. ${ }^{3}$ The urgency of dealing with work-related stress does not diminish over time. On the contrary, it is growing. The proposed amendment to Act No. 262/2006 Coll., Labour Code, contains legal protection against work stress. Paragraph 224 points out that 'Employers are required to create working conditions for employees which enable them to work safely (including preventing the risk of work-related stress and the risk of violence and harassment in the workplace and, in accordance with specific legislation, medical services). ${ }^{4}$ According to Nakonečný, the stressful nature of the present time is literally alarming. In connection with this one can name a number of factors directly related to the practice of social work - especially the fear of social insecurity, the threat of loneliness, the indifference of others, the constant hurry, the fulfilment of duties, the inability to rest, and many others. ${ }^{5}$

The term 'stress' was used for the first time by Canadian scientist Hans Selye, who described it as a state where the body must mobilise defensive or corrective mechanisms. ${ }^{6}$ In general, stress can be understood as mental overload. This is experienced either negatively - as distress (conflicting relations among social workers in the workplace, misunderstanding of clients, increasing management requirements, etc.), or positively - this is referred to as eustress (time-consuming and complicated work with a client who will gradually learn to solve his or her problems independently and he is grateful for help, etc.). ${ }^{7}$ Stress prepares the body for a specific action, that is, attack or escape. It mobilises the inner resources of an individual to be ready to attack or run. On one hand, this is a very effective reaction. On the other hand, though, it has its side effects, for example, the worsening of one's ability to think, digestion problems, a weakening of immunity, or superficial, ineffective breathing. The self-healing mechanisms of the body are thus 'displaced' into the background hand in hand with noble feelings. In the case of eustress, it goes rather the opposite way. Mild stress improves alertness, attention and motivation while, at the same time, intellectual self-control abilities are maintained. ${ }^{8}$ Křivohlavý states that stress occurs when a person comes into a stressful situation and he is pressured from various sides. ${ }^{9}$ Vágnerová recalls both 'faces' of stress, that is, that stress can be understood either as a state of an excessive strain or even a threat and, on the other hand, it can (for example) encourage the person to find

\footnotetext{
Cf. Kerstin KRASKA-LÜDECKE, Nejlepši techniky proti stresu, Prague: Grada, 2007, p. 45.

(c) MPSV, Před stresem v práci je třeba se chránit (on-line), available at: https://www.mpsv.cz/cs/7893, cited $12^{\text {th }}$ February 2018.

Amendment to Act No. 262/2006 Coll., Labour Code, as amended.

Cf. Milan NAKONEČNÝ, Psychologie..., p. 622.

Cf. Vojtěch ČERNÝ and Kateřina GROFOVÁ, Relaxační techniky pro tělo, dech a mysl, Prague: Albatros Media, 2017 , p. 7.

Cf. Milan NAKONEČNÝ, Psychologie..., pp. 616-617.

Cf. Karel NEŠPOR, Duševní pružnost v každodenním životě, Prague: Portál, 2015, p. 17.

Cf. Jaro KŘIVOHLAVÝ, Psychologie zdraví, Prague: Portál, 2009, p. 170.
} 
a solution to the situation, respectively to find 'ways out'. In such a case, it helps him to develop his or her competencies (including necessary activation and stimulation).$^{10}$ Each situation is specific in terms of the degree of stress it brings to the individual. The same situation may be cognitively treated differently by different individuals, respectively it can be differently interpreted by them. ${ }^{11}$

In social work, stress is understood as a dynamic relationship between a complex of external work demands or pressures (numerous visits to clients, many administrative activities, permanent communication with colleagues and clients, legislative parameters, etc.) and a complex of personality dispositions. It is the personality disposition that plays a crucial role in whether a social worker is able to handle demands or pressures in a reasonable way. ${ }^{12}$ Imagine a situation where a social worker is exposed to a complex of different circumstances for a long time. He regularly visits clients in their homes and conducts social surveys. At the same time, he faces a lack of time as the number of clients exceeds his or her capacity. There is a real risk that he will not manage any other, and no less necessary, duties. It may be that he also prepares documentation from social surveys undertaken and provides other inevitable administration in the framework of his or her work. Various clients, service seekers (many of whom act in an arrogant way and with some kind of readiness to act aggressively) go to the office. At work, he may occasionally face various dilemmas. And let's not forget about potential personal problems, including family problems, workplace conflicts (with colleagues or superiors, etc.). For one social worker, due to his or her specific personality disposition, these can be relatively well manageable stressors. For another social worker, though, this long-term stress can be hard to manage due to his or her specific personality dispositions. Stress can relatively easily become a factor in the development of mental illness, such as depression, burnout syndrome, and others. In professional sources, there is no doubt at this time that long-term work-related stress can influence social workers significantly in different areas. For example, in terms of reducing quality and efficiency of work, declining customer satisfaction with services provided, 'spoiling' the culture and efficiency of working organisations, etc. Let us not forget a wide range of undesirable phenomena to which long-term stress can lead. For example, routinisation of work, increased absence, maladaptation difficulties (including burnout syndrome), depression, or other health effects of long-term stress. ${ }^{13}$

Together with the threat of stress, however, there are also questions about how to manage it, respectively what strategies (not only) social workers can use in order to be able to deal with stress. This is dealt with in the following chapter which presents with this area, that is, coping strategies.

\section{Coping or the Ways of Dealing with Stress}

For the act of dealing with stress itself is often used the term coping, which is derived from the Greek word 'kolaphus' (meaning a successful attack on an opponent in boxing). The social worker, for the purposes of this article, can be treated as such a boxer who comes into into a stressful situation and copes with it by counterattacking. Dealing with stress and its process is also referred to as stress management or stress moderation. In summary, these are approaches (respectively the

10 Cf. Marie VÁGNEROVÁ, Psychopatologie pro pomáhající profese, Prague: Portál, 2004, p. 50.

11 Cf. NAKONEČNÝ, Psychologie..., p. 622.

12 Cf. Zdeněk MLČÁK, Potenciální zdroje stresu v sociální práci a jejich zvládání, Sociální práce / Sociálna práca 3/2005, p. 125.

13 Cf. MLČÁK, Potenciální..., p. 125. 
kinds of behaviour) which lead to a reduction of the tension/stress that results from it. ${ }^{14}$ Snyder, in general, states that coping is a specific response aimed at reducing physical, emotional, and psychological tension which, among other things, is related to stressful life events and day-to-day difficulties. ${ }^{15}$ Paulík also states that coping is a steady expression for an active and conscious way of managing stress. ${ }^{16}$ This is related to the fact that the individual (based on an assessment of the given situation and the assessment of his or her own choices) focuses on the goal which should result in a positive change and tolerance (while maintaining psychological balance and a positive self-image). Then the overall balance should be improved. ${ }^{17}$ The individual can deal with stress in two of the most common ways, either chooseing passive resistance or active action in order to solve the situation. Also, he has to decide for himself which solution is most appropriate. ${ }^{18}$ Thus, active action is based on the fact that the situation and the resulting stress can be solved, and the individual is ready to take active steps in this respect. An example is the situation where the management of an organisation puts the stress of constantly adding new duties on a social worker while his or her capacity has been already exceeded. The social worker initiates a management meeting at a suitable moment to outline the topic of workload and all of them together will actively discuss how to address the situation in order to help the social worker, that is, it will lead the situation towards reducing his or her work stress. Passive resistance usually comes from a situation that cannot be changed in any way. The resulting stress must be handled in such a way so as to maintain optimal psychological balance and to minimize unwanted consequences. An example may be a situation where a social worker's client - a street worker's client - dies due to an overdose. Although the social worker was making a lot of effort to help the addicted client, his or her work may now seem 'futile'. Instead, it is suitable to reconcile and interpret this situation in order to preserve one's mental balance, for example by saying, 'I did my best and, despite the circumstances, my work was not meaningless'.

An important term in the field of stress management is resilience which can be, in other words, described as toughness or resistance - that is, a certain ability to cope with a situation where one is confronted with extremely unfavourable circumstances. ${ }^{19}$ We can also meet the term hardiness. The degree of personal hardiness is important in dealing with stressful situations. It turns out that people who have higher values in the dimension of personal hardiness have many advantages. They are more likely to use effective and more active problem-solving strategies, that is, they use active action instead of passive resistance, they are physically and mentally healthier, and so on. What is also important is the coherence of an individual in two ways: in the sense of the social community (the cohesion of a group of people to which one belongs - for example, family, partner, friends, etc.) and in terms of internal unity (respectively the personal balance) - a solid character. If a person has this solid internal unity and lives in a coherent social group, he is better equipped to resist stressful situations. ${ }^{20}$

The basic and inspirational effective stress management strategies can be found, for example, in Feldman's work.

14 Cf. Jaro KŘIVOHLAVÝ, Psychologie zdraví, Prague: Portál, 2009, p. 69.

15 Cf. Charles R. SNYDER, Coping: The Psychology of What Works, Oxford: Oxford University Press, 1999, p. 5.

16 Cf. Karel PAULÍK, Psychologie lidské odolnosti, Prague: Grada, 2017, p. 118.

17 Cf. Marie VÁGNEROVÁ, Psychopatologie pro pomáhající profese, Prague: Portál, 2004, p. 57.

18 Cf. Eva BEDRNOVÁ et al., Duševní hygiena a sebeřizení pro vysokoškoláky a mladé manažery, Prague: Fortuna, 1999, p. 68.

19 Cf. Iva ŠOLCOVÁ, Vývoj resilience v dètství a dospělosti, Prague: Grada, 2009, p. 11.

20 Cf. Jitka MACHOVÁ at al., Výchova ke zdraví, Prague: Grada, 2009, p. 133. 
- Averting a threat by a challenge - if, for example, a social worker knows he has a problem with moderating conflicts with clients, he can face it by receiving assertiveness training.

- Reducing a situational threat - if a situation arises out of control, it is appropriate to correct the assessment of such a situation and thus change one's attitude towards it - for example, when a social worker is burdened with duties and thinks that he will not be able to do the job in time, he can evaluate the situation as a temporary one. The social worker can realise that he has managed far more unpleasant moments than this one - the aim is to find something good in every negative situation.

- Changing one's own goals - if an uncontrollable situation arises, it is good to set a new target - for example, a social worker who has suffered burnout syndrome as part of a high -level workload can adjust his or her work habits in a way that prevents a similar problem in the future.

- Physical action - unwanted physical effects of stress can be overcome by physical activity. For example, if a social worker is exposed to daily high psychological tension in his or her job, he can perform various activities such as running, floorball, yoga, cycling, and much more. Such activities eliminate increased blood pressure and other negative consequences of stress.

- Preventive stress training - this is also called 'stress vaccination' - it is a way of dealing with stress by obtaining information about stressors and anti-stress programmes - social workers can attend various seminars, courses, and other programmes to reduce stress or to become more resistant to stress. ${ }^{21}$

There are many available strategies which an individual can be inspired by and incorporate into his or her everyday life. Different authors present different ways of dealing with tension, stress, and negative emotions. Presenting the views of other authors is unfortunately above the capacity of this article. As far as the choice of concrete strategies for work with stress is concerned, the final decision has to be made by a particular social worker. The option of choosing a strategy that works and brings benefits at the level of psychological resilience motivates an individual to actively avert the threat and perceive stressful situations as a challenge leading to an overall change. A social worker can therefore, at his or her discretion, choose the coping strategy that suits him best. At the same time, he should reflect the forms of stress management which have been effective or ineffective for him in the past taking into account his or her personality. It must be added that social workers are 'the engine', an indispensable part of an effective helping process. ${ }^{22}$ It is therefore necessary to pay attention to the means which can develop social workers' personalities and keep mental and physical health in balance. These means can change the threat of stress into challenge mainly because of the fact that they are an effective tool for working with stress whose urgency is gradually reduced. One of these is mindfulness, a means which brings a lot of benefits to the social worker - as will be further specified.

21 Robert FELDMAN, Efektivní strategie zvládání stresu. In Milan NAKONEČNÝ, Psychologie: Přehled základních oborů, Prague: Triton, 2011, p. 624.

22 Cf. Andrej MÁTEL, Milan SCHAVEL, Pavel MÜHLPACHR and Tibor ROMAN, Aplikovaná etika v sociální práci, Brno: Institut mezioborových studií, 2010, pp. 93-94; Cf. Karel KOPŘIVA, Lidský vztah jako součást profese, Prague: Portál, 2006, p. 94. 


\section{Mindfulness as a Possible Way to Overcome the Threat of Stress by Turning It into a Challenge}

As outlined above, there are countless strategies which help to actively face the threat of stress. Given the limited capacity of the article, the author is not able to be concerned with even a minor part of such strategies. One specific strategy will be introduced which is currently on the rise and is very popular. This strategy is called mindfulness and it will be discussed in the following pages of the paper in great detail. Mindfulness is usually defined as awareness of individual moments or focusing attention on the present moment in a specific mode - i.e. without assessment and evaluation. By its nature, mindfulness promotes attention to every movement, breath, feeling, and thought. ${ }^{23}$ In general, we can say that 'mindfulness is consciousness shaped by attention in a continuous and concrete way: deliberately, in the present moment, objectively (uncritically). It can be considered as one way of meditation if we understand meditation as: 1 . systematic directing of our attention and energy; 2. influencing and transforming our experience; 3 . the recognition of the whole spectrum of humanity; and 4. our relations with other people and the world. ${ }^{24}$ Hasson concretises the core of this approach: 'Mindfulness can help a person to silence the throbbing stream of thoughts that are constantly chasing him. ${ }^{.25}$ She also mentions that we can easily imagine many moments of life in which we become mindful - fully experiencing concrete moments. For example, when we are 'immersed' in playing a board game or doing a crossword puzzle, enjoying an engaging act in a favourite book or movie or when writing an interesting letter. ${ }^{26}$ Such mindful experiences of specific activities helps the individual to be rid of the usual automated behaviour. And on the contrary, it brings him closer to the inner peace and stability that helps him to cultivate himself and to get stronger. ${ }^{27}$

We now come to the important context of mindfulness and social work. It can be a motivation and a certain starting point for (not only) stressed social workers to become more interested in mindfulness as an effective tool to fight stress. For example, due to its considerable potential to overcome the threat of stress by turning it into a challenge - that is, a step forward towards the effective treatment of stressors that affect the everyday life of a social worker both personal and professional. For one to have a specific idea, let us mention the following exemplary benefits related to the practice of mindfulness. Improving communication and comprehensibility, more effective problem solving and conflict management, increasing work efficiency and concentration, improving relationships with colleagues in the workplace, enhancing creative thinking and balance and resilience in the workplace and home environment, supporting psychological and physical wellbeing, reducing stress levels, and improving energy levels. ${ }^{28}$ In addition, a social worker (who practices mindfulness) can be more aware of those things that are dysfunctional in his or her workplace and have an appropriate critical attitude towards them. ${ }^{29}$

23 Cf. Robyn LYNN and Jo MENSINGA, Social Workers' Narratives of Integrating Mindfulness into Practice, Journal of Social Work Practice 3/2015, pp. 255-256.

24 Jon KABAT-ZINN, Mindfulness for Beginners: Reclaiming the Present Moment - and Your Life, Colorado: Sounds True, 2012 , p. 1.

25 Gill HASSON, Technika mindfulness: Jak se vyvarovat duševní prokrastinace prostřednictvím všímavosti a bdělé pozornosti, Prague: Grada, 2015, p. 28.

26 Cf. Gill HASSON, Mindfulness: Be Mindful. Live in the Moment, UK: John Wiley \& Sons, 2013.

27 Cf. Michael SINCLAIR and Josie SEYDEL, Všímavost: Cesta pro zklidnění mysli pro ty, co nestíhají, Prague: Grada, 2015 , p. 26.

28 Cf. () SSSC News, Bringing Mindfulness to Social Work (on-line), available at: http://ssscnews.uk.com/2014/11/27/bringingmindfulness-workplace-social-work, cited July 1st, 2017; cf. also Louise GRANT and Gail KINMAN, Developing Resilience for Social Work Practice, UK: Palgrave, 2014.

29 Cf. Jim ROGERS, Lucy BRIGHT and Helen DAVIES, Social Work with Adults, UK: Sage Publications, 2015. 
One can also find a number of interfaces that link social work with mindfulness. For both, the individual lived experience (in the context of one's unique life) is a crucial value. Mindfulness, as well as social work, emphasises caring for oneself and self-acceptance in its approach. Similarly, a non-evaluative approach is a hallmark of both mindfulness and social work. ${ }^{30}$ Caring for oneself is an important aspect in the practice of a social worker. He can use mindfulness in many ways to reduce stress, to calm oneself, or to increase awareness. ${ }^{31}$ It is the multivariable use that gives social workers the freedom to handle the potential of mindfulness. Puddicombe compares this to cycling. First, someone shows one how to ride a bike without specifying how to use it specifically. In the course of time, when a person is properly acquainted with a bicycle and learns how to manage it, he himself sets the purpose of usage (whether to use it in order to commute to work, to realise mental hygiene, etc.). ${ }^{32}$ In addition, mindfulness is a quality that can help to approach all situations related to the social worker's practice with clarity, concentration, and compassion..$^{33}$ It is also interesting for social work that if one wants to deal with other people (clients) permanently and consciously (that is, mindfully), he needs to develop the mindfulness of oneself first. ${ }^{34}$ At this point, it is worthwhile recalling the fact that the results of various mindfulness studies are addressed in a separate chapter of the article Mindfulness as a Potential Tool for Developing the Personality of the Social Worker. ${ }^{35}$

\section{Despite the optimistic nature of knowledge related to the effects of individual mindfulness,} it is also necessary to bear in mind the potential negative consequences and, consequently, the risks. Due to the lack of relevant scientific knowledge, the risks cannot yet be highlighted. An example of possible undesirable consequences can be the development of the 'contemplative dissociation', that is, the absence of interconnection of thoughts, emotions, and bodily feelings. This, according to experts, arises through permanent attention to the body leading to a situation in which the individual practicing mindfulness touches a past physical or psychological trauma characterised by a lack of adequate processing. This can, among other things, cause unwanted emotional imbalance, which is complicated to heal afterwards. ${ }^{36} \mathrm{~A}$ summary of the studies that reported adverse side effects among practitioners of different types of meditation (including mindfulness meditation) was also elaborated. These include, for example, depersonalisation (a feeling of disconnection from mental processes or from the body), psychosis (loss of contact with reality) with delusions, hallucinations and unorganised manifestation, anxiety, increased risk of seizures, loss of appetite, or insomnia. However, the research team itself mentions that the practice of the screening of practitioners, safety limits for research, or standards for the training of researchers have not been processed yet. ${ }^{37}$ Therefore, such research needs to be further pursued in order to obtain a greater clarification of the real risks associated with the practice of mindfulness.

30 Cf. Francis J. TURNER, Social Work Treatment: Interlocking Theoretical Approaches, Oxford: Oxford University Press, 2017, pp. 335-336.

31 Cf. Aneesha KELLY and Ifeoma OKOLO, Mindfulness Meditation as a Self-Care Practice in Social Work, in: Master of Social Work Clinical Research Papers, Minnesota: School of Social Work, 2016, p. 2.

32 Cf. Andy PUDDICOMBE, Uklidte si v hlavě: stači 10 minut denně, Prague: Grada, 2016, p. 20.

33 Cf. Edward R. CANDA and Leola D. FURMAN, Spiritual Diversity in Social Work Practice: The Heart of Helping, Oxford: Oxford University Press, 2010, p. 362.

34 Gabriele ROSSBACH, Síla přítomného okamžiku: 15 meditačních cvičení pro plnější a radostnější život, Prague: Grada, 2014 , p. 28.

35 Cf. Michal KACZOR, Všímavost (mindfulness) jako potenciální nástroj rozvoje osobnosti sociálního pracovníka, Caritas et Veritas 2/2017, pp. 40-50.

36 Cf. David TRELEAVEN, Meditation, Trauma, and Contemplative Dissociation, Somatics: Magazine-Journal of the Mind/Body Arts and Sciences 2/2010, pp. 20-22.

37 Cf. Kathleen B. LUSTYK, Neharika CHAWLA, Roger S. NOLAN, Alan MARLATT, Mindfulness Meditation Research: Issues of Participant Screening, Safety Procedures, and Researcher Training, Advances 1/2009, pp. 20-30. 
The next and last chapter deals with the actual realisation of the challenge potential, that is, what are the options for social workers to develop and maintain mindfulness? There is a whole range of comprehensive and structured programmes amongst which you need to choose the right one. Concretely, this is the one which (by its focus and specific content) corresponds to the expectations of the trainee - social worker.

\section{Realising the Challenge Potential - Developing and Maintaining Mindfulness}

If a social worker decides to use mindfulness as an effective tool for working with stress, it is also important to choose an approach that is close to him. We are talking mainly about coherent and structured programmes based on the cultivation of mindfulness. There are plenty of them available. A certain 'gold standard' is an eight-week programme, internationally called Mindfulness-Based Stress Reduction (MBSR), or a stress-reduction programme based on the principles of mindfulness compiled by Jon Kabat-Zinn at the University of Massachusetts. But there is an increasing number of other programmes directly derived from the basic MBSR. For example, there is Mindfulness-Based Cognitive Therapy (MBRT), that is, a cognitive therapy based on mindfulness, Mindfulness-Based Relapse Prevention (MBRP), that is, a relapse prevention programme built on the basis of mindfulness, or Mindfulness-Based Relationship Enhancement (MBRE), that is, a programme to improve partner relationships through mindfulness. ${ }^{38}$ For the purposes of this article, we will approach two widely represented and usually implemented programmes, MBSR and MBCT. These have become a well-known standard over time. In addition, they have been the subject of various studies for a long time and thus have become empirically validated in this respect. Each of these programmes has a different background, particularly in the sense of the target group and theoretical inspiration. Both MBSR and MBCT have a common format. Both develop a plethora of skills that support human mindfulness. ${ }^{39}$ Another undisputable advantage is that a social worker can use them, if necessary, in both directions. That is, both in his or her own personality development and in his or her interventions with clients. Mindfulness can be well applied to a wide range of clients, such as those who suffer from depression, anxiety, those who are in permanent stress and tension, or have low self-confidence, and so on.

MBSR (Mindfulness-Based Stress Reduction) - is an eight-week course that usually consists of two-and-a-half (or alternatively, three-hour) meetings each week. Between the sixth and seventh week there is usually a day-long meeting based on silent practice of mindfulness. Everyday home practice is a matter of course. The MBSR programme is designed for those who are interested in learning how to effectively deal with stress through their own resources, thereby enhancing overall quality of life. ${ }^{40}$ The programme was established in the 1970s in the United States by Jon Kabat-Zinn. It has been used particularly in a clinical setting when working with individuals with a wide range of diagnoses - for example, to deal with stress excess, but also addiction to addictive substances or chronic pain..$^{41}$ The programme is based mainly on self-observation and stress management using formal stress-reducing techniques such as yoga. Participants are encouraged

38 Cf. Ed HALLIWELL, Mindfulness: How to Live Well by Paying Attention, USA: Hay House, 2015.

39 Cf. GERNER, SIEGEL and FULTON, Mindfulness..., p. 124; cf. Jenny WANG and Juliet ADAMS, Bringing Mindfulness to Your Workplace, USA: Association for Talent Development, 2016, p. 8.

40 Cf. Linda LEHRHAUPT and Petra MEIBERT, Mindfulness Based Stress Reduction: The MBSR Program for Enhancing Health and Vitality, Novato: New World Library, 2017, p. 3.

41 Cf. Shamash ALIDINA and Juliet ADAMS, Mindfulness at Work Essentials for Dummies, USA: John Wiley \& Sons, 2014. 
to become more aware of stressors in day-to-day activities. During the course of the programme, there is also a mutual discussion between the participants. It is intended primarily to support individual learning. ${ }^{42}$

MBCT (Mindfulness-Based Cognitive Therapy) - a programme created by Zindal Segal, Mark Williams, and John Teasdale in the 1990s. The aim was to help people with depression (in a clinical setting). The MBCT programme combines mindfulness with cognitive behavioural therapy, and is, in contrast to MBSR, more focused on helping people work effectively with their minds. ${ }^{43}$ However, it is closely related to MBSR and shares most of its content with this programme. The main difference between them is that MBSR focuses on mental illness (such as stress, anxiety, fear) in general, and MBCT focuses more on how one thinks. It is very effective in working with stress, anxiety, depression, and similar problems of psychological origin. The MBCT programme works well with the autopilot mode which plays an important role in case of many individuals suffering from these problems. Autopilot puts man in purely automated and accustomed reactions, thus keeping him in the known patterns of behaviour. However, with regard to problems of psychological origin, they may be very undesirable and may form a 'vicious circle' of recurring problems which, in addition, were not clearly understandable for an individual due to his or her automated behaviour. ${ }^{44}$

It should be added that, in the Czech Republic, MBSR courses are available under the guidance of a qualified lecturer, Mgr. Jaroslav Chýle (CFM Qualified MBSR Teacher). He gained a qualification directly at the Center for Mindfulness at the Medical Faculty of the University of Massachusetts. ${ }^{45}$ Apart from the abovementioned organised and structured ways of mindfulness training (that is, outside of various programmes such as MBSR and MBCT), the social worker has the option to choose his or her own way. This may be the case when he does not enjoy working in a team (an integral part of the organised courses) or if the payment for the programme is too high for him, and in other similar situations. There are many professional publications, such as the work by Jon Kabat-Zinna, 'Full Catastrophe Living: Using the Wisdom of Your Body and Mind to Face Stress, Pain, and Illness' ${ }^{46}$ which are designed as a specific manual, respectively another alternative of mindfulness training. In any case, the crucial factor in a social worker's life is not 'to rest on one's laurels' but to act actively. Passivity can easily bring an individual into a seemingly hopeless situation, when he can get the impression that the burden, respectively stress cannot be overcome and he becomes its victim. As outlined in this article, this is far from the truth. The phenomenon of mindfulness needs to be explored in connection with the practice of social work and there is a need to bring new knowledge as it is insufficient at this time. Such development can also help social workers to find stable support in mindfulness and use it as a tool to overcome the threat of stress by turning it into the challenge for overall change.

42 Cf. Malcolm PAYNE, Modern Social Work Theory, Oxford: Oxford University Press, 2016, p. 167.

43 Cf. ALIDINA and ADAMS, Mindfulness...

44 Richard SEARS, Building Competence in Mindfulness-Based Cognitive Therapy: Transcripts and Insights for Working With Stress, Anxiety, Depression, and Other Problems, New York: Routledge, 2015, p. 1.

45 Note: more information can be found on the official website: http://www.mbsr.cz/.

46 Cf. Jon KABAT-ZINN, Život samá pohroma: Jak čelit stresu, nemoci a bolesti pomocí moudrosti těla a mysli, Brno: Jan Melvil Publishing, 2016. 


\section{Conclusion}

The article has dealt with stress as a threat as well as a challenge for social workers and their professions. In the first chapter stress was comprehensively presented, mainly its conception given by individual authors. Important social warnings against the stress of the 21 st century presented by the Ministry of Labour and Social Affairs or the World Health Organisation were mentioned. This was followed by the second chapter with closer presentation of the problem of coping, that is, the ways in which an individual (a social worker) copes with stress. Also, related terms were presented, that is, resilience, personal hardiness, or coherence. It is a fact that social workers have the choice to choose a strategy that is effective in their personal needs and settings and brings benefits (among others) to the level of psychological resilience. It is precisely such a strategy that stimulates them actively to avert the threat and to perceive stressful situations as a challenge to overall change. In the next chapter, mindfulness was introduced as one of the possible tools, respectively one of the potential effective strategies for working with stress. This gives the social worker the opportunity to overcome the threat of stress / burden and turn it into a challenge. The challenge here is primarily presented by the fact that the social worker should begin to solve the burdens using such a tool and, at the same time, effectively eliminates stress. Finally, the practice of mindfulness was further elaborated in the last chapter which dealt with the realisation of the challenge potential, that is, the ways in which the social worker can develop and maintain mindfulness. These are the various programmes available based on the philosophy of mindfulness. The article focused on the two most common and empirically verified programmes, that is, MBSR and MBCT. However, it is still necessary to pay attention to the phenomenon of mindfulness in social work and to bring new empirical knowledge which is currently weak - especially in the context of Czech social work.

\section{Contact}

\section{Michal Kaczor MA}

University of South Bohemia in České Budějovice

Faculty of Theology, Department of Ethics, Psychology and Charity

Kněžská 8, 37001 České Budějovice

info@michalkaczor.cz 